\title{
Examination of vertical green facades and green roofs in terms of ecological criteria and evaluation of energy efficiency
}

\author{
Düşey yeşil cepheler ve yeşil çatıların ekolojik kriterler bakımından incelenmesi ve enerji \\ verimliliğinin değerlendirilmesi
}

Hande Büşra GEYİKLi*1a, Fatih CANAN ${ }^{1 b}$

${ }^{1}$ Konya Technical University, Faculty of Design and Architecture, Department of Architecture, 42250, Konya

• Geliş tarihi / Received: 28.04.2021 • • Düzeltilerek geliş tarihi / Received in revised form: 21.06.2021 • Kabul tarihi / Accepted: 05.07 .2021

\begin{abstract}
In this study, it is aimed to determine the results of the usage of vertical green façade and green roof systems which are increasing in use today, in four different climatic zones of our country, considering the annual heating, cooling and total energy consumption. Based on a building model in the study, the effect of the green facade and green roof applications on the buildings' annual heating and cooling loads was tried to be determined for four cities of our country with four different climatic characteristics. In selected cities in these climate regions, a traditional building and buildings with vertical green facades and green roof applications were compared. Situated in Turkey's four different climatic zones with the results achieved in this study was found to be differences in four different city's annual energy consumption. In the annual total energy consumption; Antalya city with $2.68 \%$ as a result of application of only planted roof systems, Konya city with $11.64 \%$ as the result of application of only vertical green façade systems, and highest benefit rates in Erzurum city with application of both systems and $14.38 \%$ at the end. As a result of this, considering the annual total energy consumption, green facades and green roof applications in buildings are found to have a positive effect on the energy performance of the building, even though it does not vary from region to region.
\end{abstract}

Keywords: Ecology, Energy efficiency, Green roof, Green wall, Sustainable architecture

$\ddot{O} z$

Bu çalışmada, günümüzde kullanımı artan düşey yeşil cephe ve yeşil çatı sistemlerinin ülkemiz sinırlarında dört farklı iklim bölgesindeki kullanımının yıllık ısıtma, soğutma ve toplam enerji tüketimleri dikkate alındığında ne gibi sonuçlar vereceğinin tespit edilmesi amaçlanmuştır. Çalışmada, bir bina modeli esas alınarak düşey yeşil cephe ve yeşil çatı uygulamalarının, binaların yıllık ısitma ve soğutma yüklerine etkisi, ülkemizin dört farkl iklim özelliğine sahip dört kenti için belirlenmeye çalışllmuştır. Bu iklim bölgelerinde seçilen kentlerde, geleneksel bir bina ile düşey yeşil cephe ve yeşil çatı uygulamalarının kullanıldı̆̆ binalar karşılaştırllmıştır. Ulaşılan sonuçlar ile Türkiye'nin dört farklı iklim bölgesinde yer alan dört farklı kentin ylllk tüketim enerjilerinde farklllıklar olduğu saptanmıştır. Yıllık toplam enerji tüketiminde; sadece bitkilendirilmiş çatı sistemlerinin uygulanması sonucunda \%2.68 ile Antalya kenti, sadece düssey yeşil cephe sistemlerinin uygulanması sonucunda \%11.64 ile Konya kenti, her iki sistemin uygulanması soncunda ise \%14.38 ile Erzurum kentinde en yüksek fayda oranları sağlanmıştır. Bunun sonucunda, yıllık toplam enerji tüketimleri dikkate alındı̆̆ında, binalarda yeşil cephe ve yeşil çatı uygulamalarının, bölgeden bölgeye farklılık göstermesine rağmen binanın enerji performansinı olumlu yönde etkilediği saptanmıştır.

Keywords: Ekoloji, Enerji verimliliği, Yeşil çatı, Yeşil duvar, Sürdürülebilir mimarlık

\footnotetext{
${ }^{* a}$ Hande Büşra GEYIKLİ; hbkobya@gmail.com, Tel: (0537) 51375 35, orcid.org/0000-0003-2970-9921

${ }^{\mathrm{b}}$ orcid.org/0000-0003-4469-1993
} 


\section{Introduction}

Nowadays, urbanization causes many social, economic and environmental negativities. In the man-made urban environment, the existing ecosystem, climate and urban atmosphere are changing. Unfortunately, the effects of this situation on human life are negative. Air pollution and urban heat island effect are the most important of these and adversely affect the health and life of the person in general. Reducing green vegetation, increasing concrete surfaces and intensive consumption of fossilized energy resources are the main human actions of the aforementioned adverse effects.

In the process from the 1970s to the present in the world and in our country, in the environmentthemed conferences organized by the United Nations and in studies conducted in nongovernmental organizations, solutions were tried to be found to overcome negative environmental developments. In discussions about creating solutions, strategies to reduce negative environmental impacts are encountered in planning and design scales (urban planning, building design) that affect the formation of the built environment. Reducing fossil-based energy consumption in buildings and increasing urban green areas are some of them. In order to achieve this goal, vertical green facades and green roofs are offered in solution suggestions. In current architectural applications, sustainable structures such as vegetation used on the facade and roof, environmentally friendly building materials and environmentally adaptable building elements have started to be produced. Vertical green facade and green roof systems are frequently preferred in today's architectural applications due to the improvement of the energy performance of buildings and the benefits they bring to the city atmosphere and the city's ecosystem.

It has been proven by various studies that green roofs and vertical green facades provide many positive effects for the building and the environment in which they are used (Besir and Cuce, 2018; Saadatin et al., 2013; Manso et al., 2021; Andric et al., 2020). These are contributing to the biodiversity in the region where it is located (Jusselme, 2019), regulating the air quality by reducing the $\mathrm{CO}_{2}$ level and increasing the $\mathrm{O}_{2}$ level (Liu, et al., 2021; Baik et al., 2012), helping to reduce the urban heat island effect (Sanhez and Reames, 2019; Herath et al., 2018; Asadi, 2020), contributing to rainwater management (ScholzBarth, 2001; Xu et al., 2020; Mentens et al., 2006), reducing the temperature (Andric et al., 2020; Coma et al., 2017; Mazzali et al., 2012), providing thermal insulation (Dede et al., 2020), preventing the wind, providing sound insulation (Azkorra et al., 2015; Galbrun and Scerri, 2017; Wong et al., 2010), shading (Vox et al., 2018; Perez Luque et al., 2017), reducing energy consumption, increasing visual value (Sutton, 2014; Jungels et al., 2013), providing recreation area (Peck, 1999), effect on fire safety (Susurova, 2015), protection against UV rays and its effect on human health (Dadvand and Nieuwenhuijsen, 2019).

Vertical green facade and green roof applications enable the emergence of new plant communities thanks to the plant layer they contain and create a food source for insects, birds and invertebrates. In fact, it has been proven by many studies that these practices cause the formation of various animal species in some regions (Jones, 2002). The plant layer also helps to clean the air by providing photosynthesis, the balance of $\mathrm{CO}_{2}$ and $\mathrm{O}_{2}$ in the air, the removal of dirty gases, and the removal of particles and dusts (MacDonagh, 2005). Temperature increase can be prevented by the plants shading, evaporation through evapotranspiration and storage properties, and the condition of cities being warmer compared to rural areas, which is called urban heat island, can be reduced (Luckett, 2009).

While vertical green facades and green roofs reduce the temperature in the summer months, they also adjust the heat level of the spaces by providing thermal insulation in the winter months. Thus, these systems provide energy savings by minimizing energy consumption in the places where they are used (Alexandri and Jones, 2008). Apart from this, vertical green facades are used on the facades of the buildings to provide shade in the space and contribute to the cooling of the space. It can reduce the wall surface temperature up to $14^{\circ} \mathrm{C}$ compared to wall surfaces exposed to the sun (Tilley et al., 2012). Therefore, the energy used for air conditioning of the buildings is saved, the thermal performance of the buildings is increased and energy consumption is reduced (Loh, 2008; Papadakis et al., 2001). Energy savings can also be achieved by preventing wind. The wind causes the air temperature inside the space to drop significantly during the winter months (Perez et al., 2011). Thanks to plants, wind insulation is provided, preventing the internal temperature of the building from falling and contributing to energy efficiency. Plants also protect the insulation layer by reducing the bad effects of UV rays. Thus, it 
makes the building more durable (Hasan et al., 2012).

The potential of green roofs in providing recreation areas is quite high. Especially intensive roofs can create a socialization space for the urban dweller. Apart from recreational use, agriculture can also be done on the roof, especially with soil thickness up to $30 \mathrm{~cm}$ (Francis et al., 2014). This soil layer and plant materials also have sound absorption properties (Aksoy and İçmek, 2010). It has a very good sound insulation especially in low frequency sounds. A sparsely vegetated green roof can reduce the sound by around 40 decibels, while a densely planted roof can reduce the sound by around 46-50 decibels (Peck et al., 1999).

It has been proven by many studies that the accessibility of the open space and natural environment views have a positive effect on human health. Studies have proven that even visual access to a natural environment can reduce stress and ailments and improve overall health, job satisfaction and productivity (Ulrich, 1984; Dadvand and Nieuwenhuijsen, 2019). At the same time, thanks to the plants, negative perceptions in a space improve and the general profile of the space becomes stronger. These practices are the cheapest and fastest way to significantly improve the main visual, economic and social conditions of the city (Mir, 2011).

In the study, the benefits of vertical green facade and green roof systems, which are increasingly used, to the ecosystem are stated and it is aimed to determine in which climatic region and under which conditions a traditional residential building and a residential building with vertical green façade and green roof systems will give better results. A comparison of annual heating and cooling loads achieved by using vertical green facade and green roof applications was made for Antalya, Samsun, Konya and Erzurum selected from four different climatic regions of Turkey.

\section{Materials and methods}

In the study, in order to evaluate the energy efficiency of vertical green facades and green roofs, Antalya (1. climate region), Samsun (2. climate region), Konya (3. climate region) and Erzurum (4. climate region) were selected from Turkey. The purpose of selecting these cities is to determine and compare the annual energy performances of vertical green façade and green roof systems in different climatic zones. At the same time, the energy performances of a traditionally constructed residential building and a residential building with vertical green façade and green roof systems were compared (Kobya, 2017).

The simulation program used in the study, Design Builder (DesignBuilder, 2017), is an EnergyPlusbased software tool developed to measure and control the performance of building designs in terms of energy, carbon, lighting and comfort (Altensis, 2015). Design Builder; is a visual simulation program developed for the energy, carbon emission, lighting and comfort control of the building. Using the Design Builder, the IDF files required for EnergyPlus are created, the building model can be prepared and the necessary corrections can be made on the model for energy analysis (Aktacir et al., 2011).

The simulation process consists of 5 different stages. These are listed as follows:

- Determining the building model to be simulated

- Transferring the building model to the Design Builder program

- Identifying common and different options for the transferred building model

- Calculation of the annual total energy loads in all four cities for the created options

- Evaluation of the calculated values for each four cities and different options

The cities of Antalya, Samsun, Konya and Erzurum, which are located in the 1,2,3 and 4th climatic zones according to TS 825 standards, are respectively in the $\mathrm{Csa}, \mathrm{Cfb}$, BSk and Dfb class according to the Köppen climate classification (Köppen, t.y.). It is aimed to compare the annual heating, cooling and total energy consumption in these cities. For this, a residential building model was designed and calculations were made. The building model created is considered as a threestorey residential building with a total of $280 \mathrm{~m}^{2}$ consisting of two flats (Figure 1). 


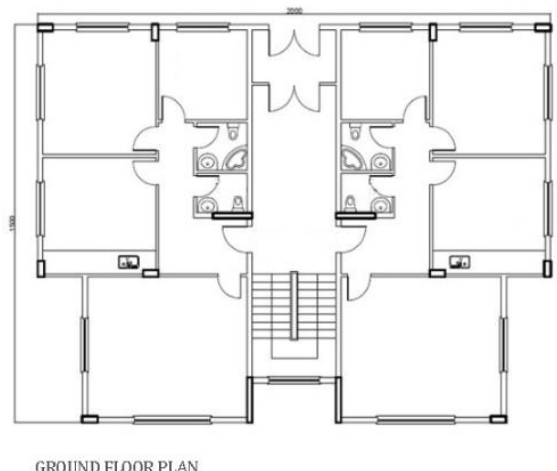

Figure 1. Floor plans of the model

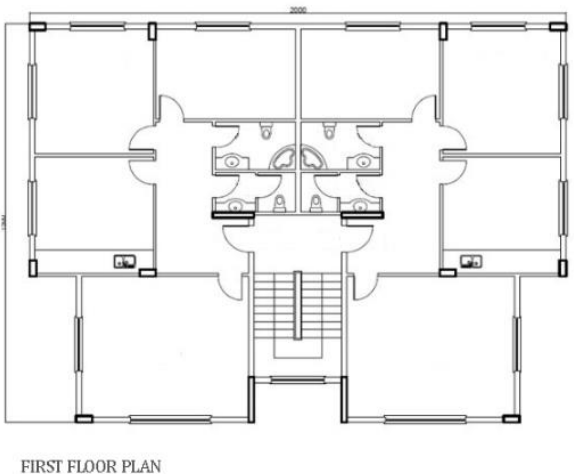

FIRST FLOOR PLAN
Based on the selected building model, firstly, common features for all parameters are determined. Features such as the size of the selected building, the usage function, the number of users, the ratio of windows and doors, its form, and its orientation have been shared in all parameters. The exterior material used and the material layers used on the flat roof are considered as variable properties. Interior divider walls, doors and windows are also taken into account in the created model. The floor height has been calculated as $300 \mathrm{~cm}$ including the floor layer. XPS (Extruded polystyrene foam) has been preferred as the thermal insulation material. While determining the thermal insulation layer for four different cities, the $\mathrm{U}$ values given in the "TS 825 Thermal Insulation Rules in Buildings" standards were taken into account. Thermal insulation thicknesses were calculated accordingly. Then, the building model was transferred to the Design Builder program and common and different layers were created for all parameters. First, the residental building was modeled, including interior wall partitions and window-door openings (Figure 2).

\begin{tabular}{|l|c|c|c|}
\hline \multirow{2}{*}{} & \multicolumn{3}{|c|}{ Calculated Thermal Insulation Thicknesses } \\
\cline { 2 - 4 } & Wall (cm) & Roof (cm) & Floor (cm) \\
\hline Antalya & 4 & 6 & 1 \\
\hline Samsun & 4 & 7 & 1 \\
\hline Konya & 6 & 10 & 3 \\
\hline Erzurum & 7 & 12 & 4 \\
\hline
\end{tabular}

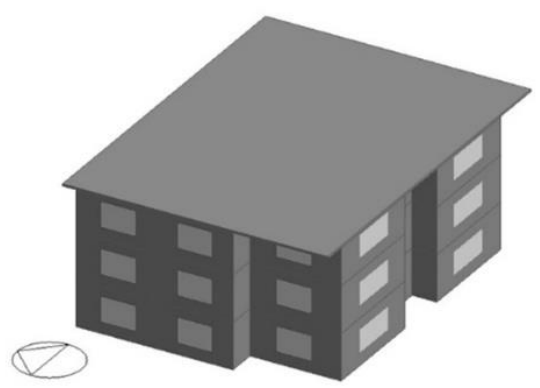

Figure 2. Calculated thermal insulation thicknesses and the model created in the Design Builder program

In the model, the weather data of the Meteonorm program were used for the climate data of Antalya, Samsun, Erzurum and Konya cities (Figure 3). Totally, 16 different options are created in line with the default parameters. These options are listed and coded as shown in the table below to avoid confusion (Table 1).
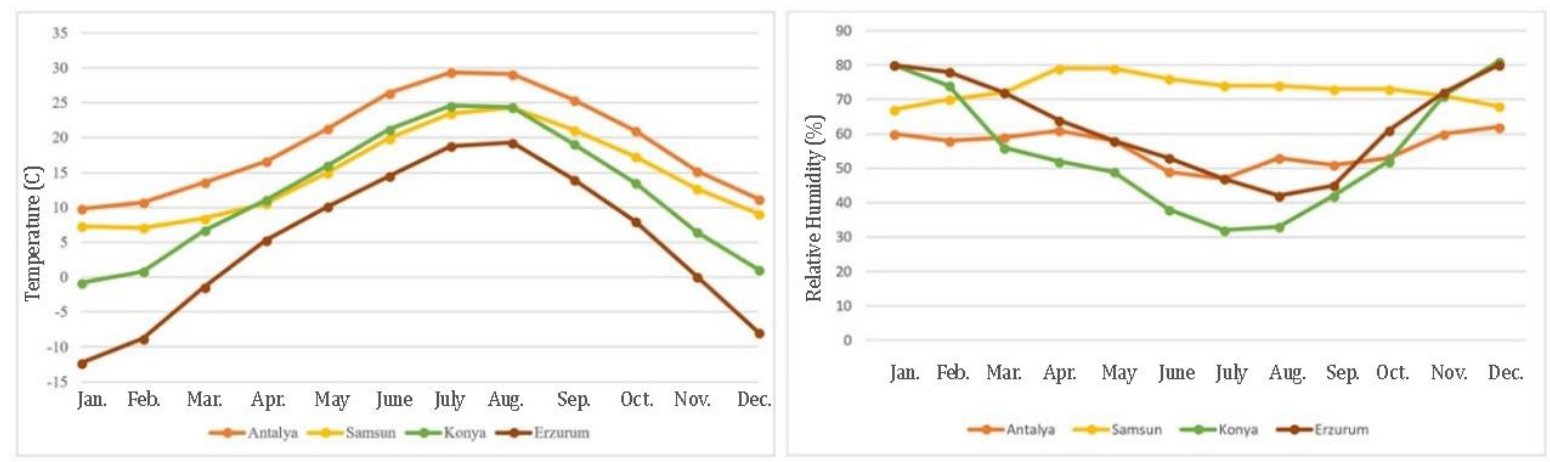

Figure 3. Meteonorm temperature and humidity values 
Table 1. 16 different options and coding based on default parameters

\begin{tabular}{ccc}
\hline & Wall & Roof \\
\hline $\mathbf{1}$ & Traditional wall & Traditional roof \\
$\mathbf{2}$ & Traditional wall & Green roof \\
$\mathbf{3}$ & Green wall & Traditional roof \\
$\mathbf{4}$ & Green wall & Green roof \\
\hline & A: Antalya & S: Samsun \\
& K: Konya & E: Erzurum
\end{tabular}

A1: Housing built with traditional wall and traditional roof in Antalya

S3: Housing built with a green wall and a green roof in Samsun

\section{Results}

The results achieved by different cities are as follows:

Antalya: Data 1 which traditional roof and traditional wall are the highest annual heating load values for Antalya. This is followed by data 2, 3 and 4, respectively. For the annual cooling loads, the cooling load of data 1 using traditional roof and traditional wall is the most. This value is followed by traditional wall and green roof option, which is the data 2 . The lowest value is green wall and green roof option. The annual total energy consumption for Antalya, decreases from data 1 to data 4 . These results show that the use of green wall and green roof benefit the total energy consumption in Antalya province (Figure 4).

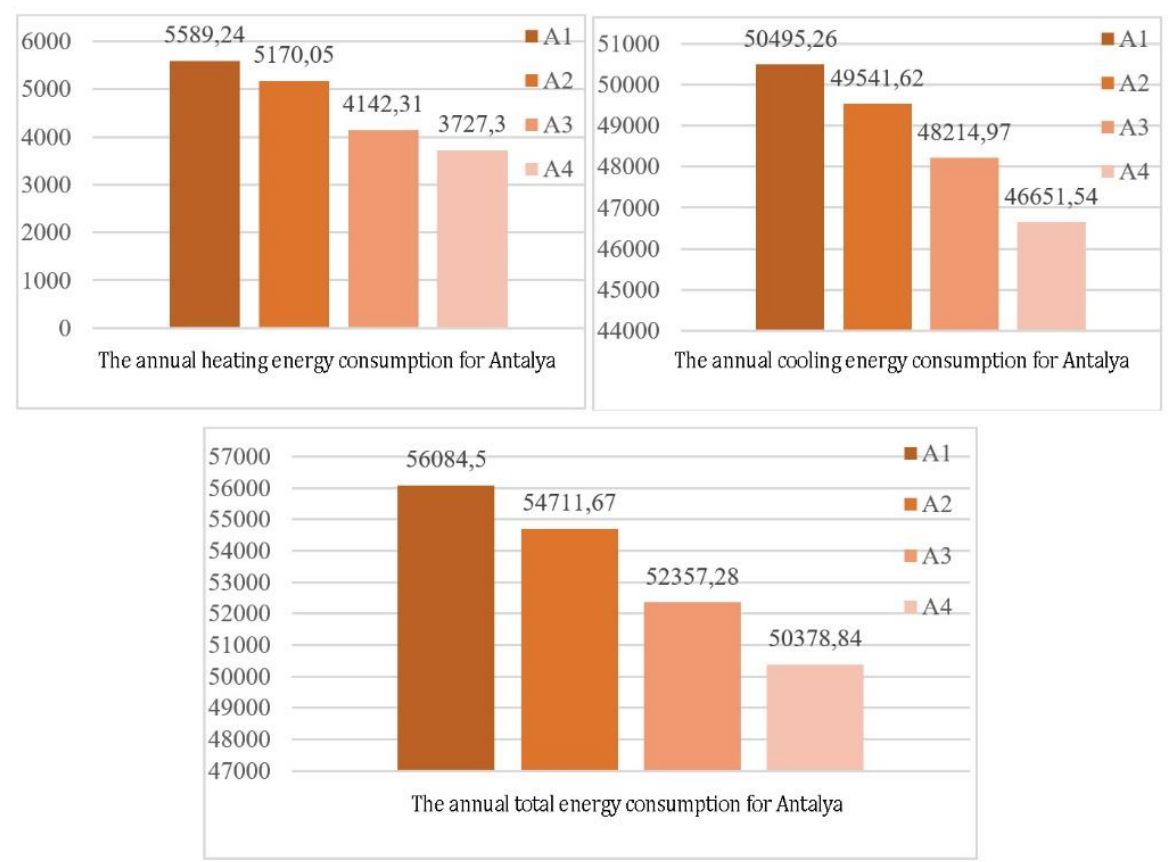

Figure 4. Annual heating, cooling and total energy consumption values of Antalya city $(\mathrm{kWh})$

Samsun: Data 1 which the traditional roof and traditional wall options is the highest among the annual heating load values for the city of Samsun. This is followed by data 2, 3 and 4, respectively. For the annual cooling load, it is the data 1 using traditional roof and traditional wall most. This is followed by data 3 and then data 2 . The lowest value is the data 4 using green wall and green roof options. The annual total energy consumption for Samsun decreases from data 1 to data 4 (Figure 5). 


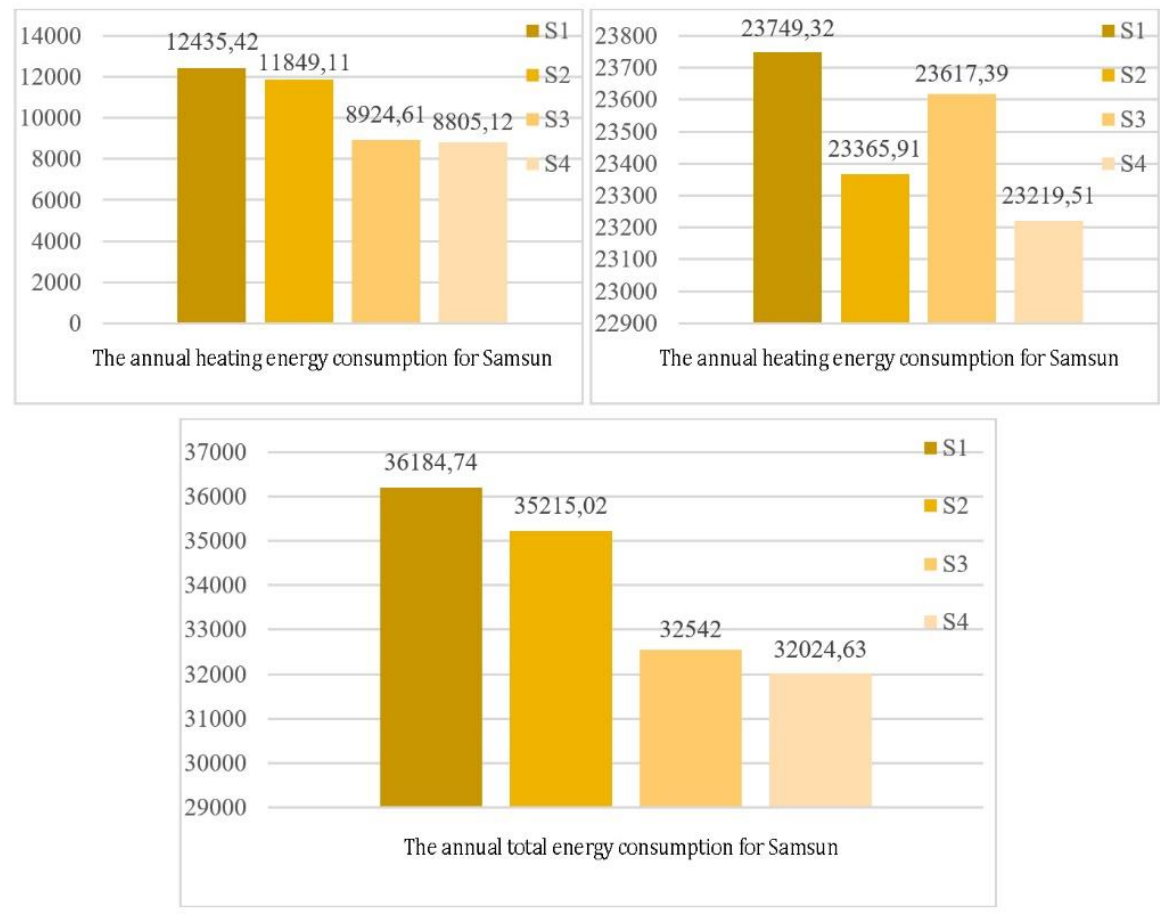

Figure 5. Annual heating, cooling and total energy consumption values of Samsun city (kWh)

Konya: The highest annual heating value for Konya city is the data 1 using traditional roof and traditional wall. This is followed by data 2,3 and 4. Among the annual cooling load values for Konya city, data 2 using traditional roof and green wall is the highest value. This is followed by data 3 and then data 1 . The lowest value is data 4 using green wall and green roof options. The annual total energy consumption for Konya is the highest in data 1 , followed by data 2,3 and 4 , respectively. These results show that option 4 , which combines the use of green wall and green roof, works best (Figure 6).

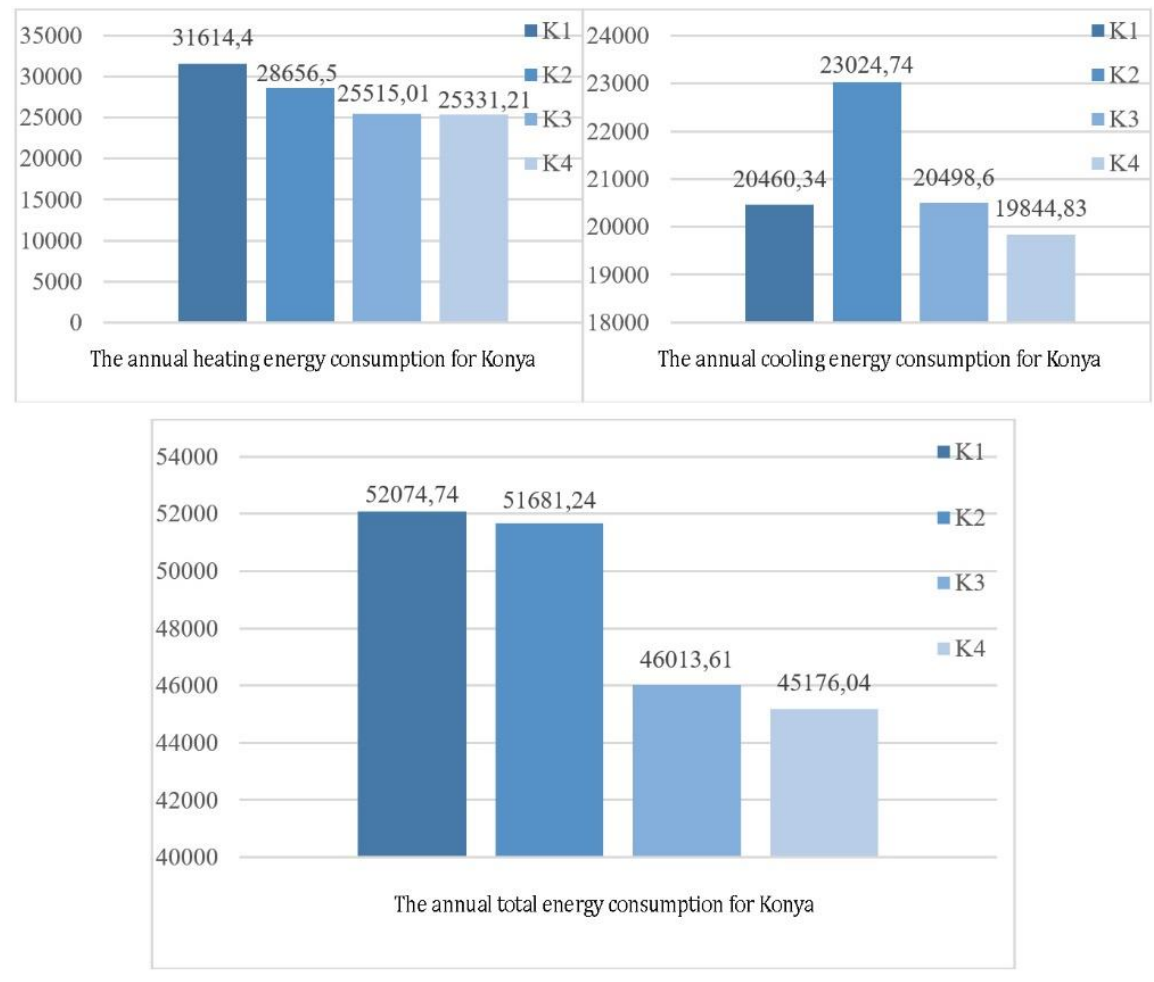

Figure 6. Annual heating, cooling and total energy consumption values of Konya city (kWh) 
Erzurum: The highest annual heating value for Erzurum city is the data 1 using traditional roof and traditional wall. This is followed by data 2, 3 and 4. respectively. The highest annual cooling value is the data 3 . This is followed by data 4 and then data 1 . The lowest value is data 2 , using traditional wall and green roof option. The annual total energy consumption for Erzurum is the highest in data 1, followed by data 2, 3 and 4, respectively. These results show that the use of green wall and green roof benefit the annual total energy consumption in Erzurum city (Figure 7).

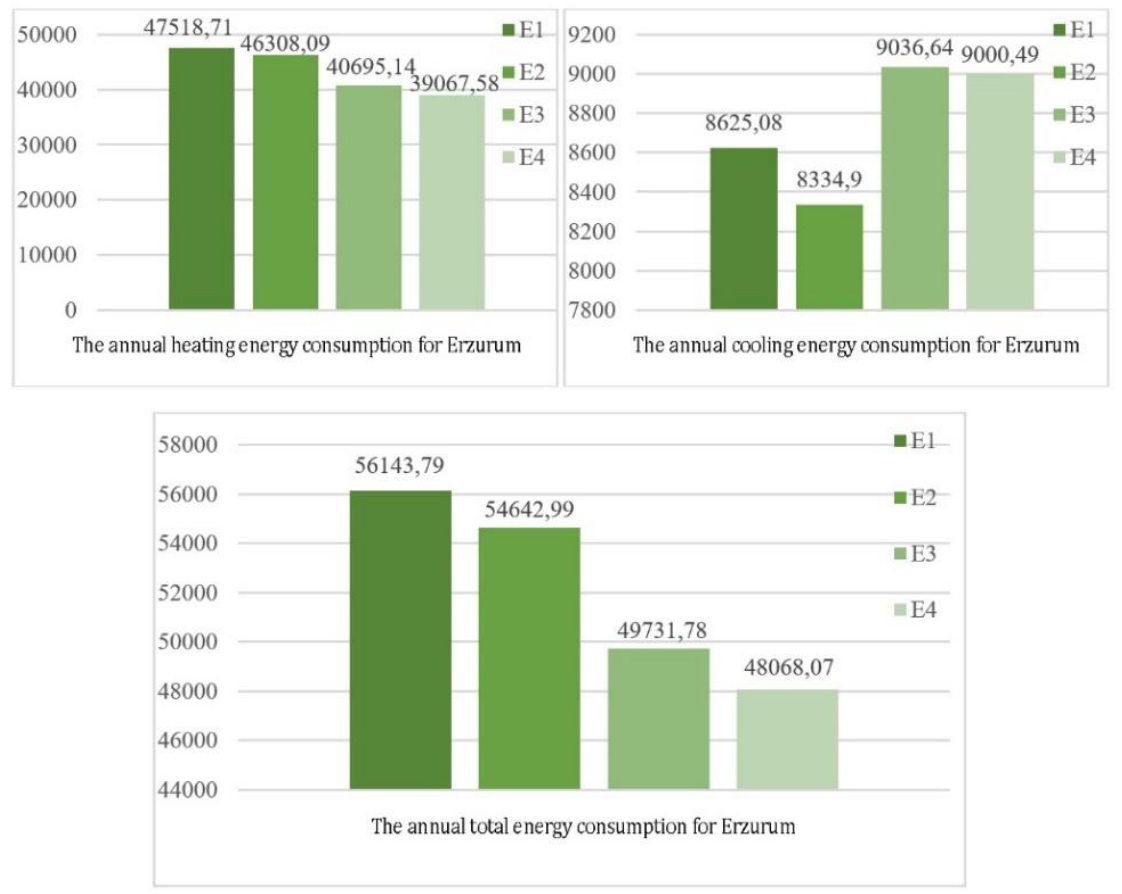

Figure 7. Annual heating, cooling and total energy consumption values of Erzurum city (kWh)

According to the results, the benefit rates provided by the use of green wall and green roof compared to traditional roof and traditional wall options are given in table 2 for the cities of Antalya, Samsun, Konya and Erzurum.

Table 2. Benefit rates for four different cities

\begin{tabular}{cccc}
\hline & $\begin{array}{c}\text { Benefit ratio for annual } \\
\text { heating consumption }(\boldsymbol{\%})\end{array}$ & $\begin{array}{c}\text { Benefit ratio for annual } \\
\text { cooling consumption }(\boldsymbol{\%})\end{array}$ & $\begin{array}{c}\text { Benefit ratio for annual } \\
\text { total energy consumption } \\
(\%)\end{array}$ \\
\hline $\mathbf{A 2}$ & 7.50 & 1.89 & 2.45 \\
$\mathbf{A 3}$ & 25.89 & 4.52 & 6.65 \\
$\mathbf{A 4}$ & 33.31 & 7.61 & 10.17 \\
$\mathbf{S 2}$ & 4.71 & 1.61 & 2.68 \\
$\mathbf{S 3}$ & 28.23 & 0.55 & 10.07 \\
$\mathbf{S 4}$ & 29.19 & 2.23 & 11.50 \\
$\mathbf{K 2}$ & 9.36 & -12.53 & 0.76 \\
$\mathbf{K 3}$ & 19.29 & -0.19 & 11.64 \\
$\mathbf{K 4}$ & 19.87 & 3.01 & 13.25 \\
$\mathbf{E 2}$ & 2.55 & 3.36 & 2.67 \\
$\mathbf{E 3}$ & 14.36 & -4.77 & 11.42 \\
$\mathbf{E 4}$ & 17.78 & -4.35 & 14.38 \\
\hline
\end{tabular}

In figure 8, the benefit rates obtained in annual total energy consumption by using traditional walls and green roofs for four cities are given. According to this chart, the highest rate of benefit achieved by using traditional walls and green roofs is realized with $2.68 \%$ in Samsun, which is located in the 2nd climate zone. This is followed by Erzurum in the 4th climate zone with a rate of $2.67 \%$ and Antalya in the 1 st climate zone with a rate of $2.45 \%$. In Konya, which is located in the 3rd climate zone, the least benefit is provided with $0.76 \%$. 


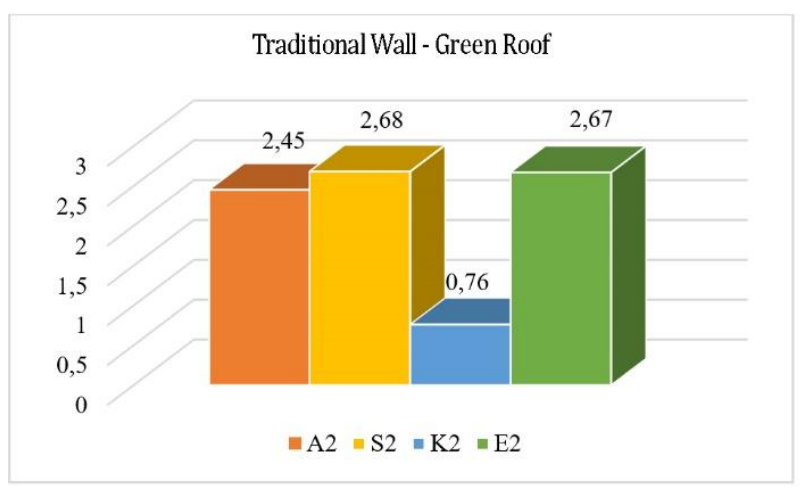

Figure 8. Benefit rates in traditional walls and green roofs (\%)

In figure 9 , the benefit rates obtained in annual total energy consumption by using green walls and traditional roofs for four cities are given. According to this chart, the highest rate of benefit achieved by using traditional walls and green roofs is realized with $11.64 \%$ in Konya, which is located in the 3rd climate zone. This is followed by Erzurum located in the 4th climate zone with $11.42 \%$, Samsun in the 2nd climate zone with $10.07 \%$ and Antalya in the 1st climate zone with $6.65 \%$.

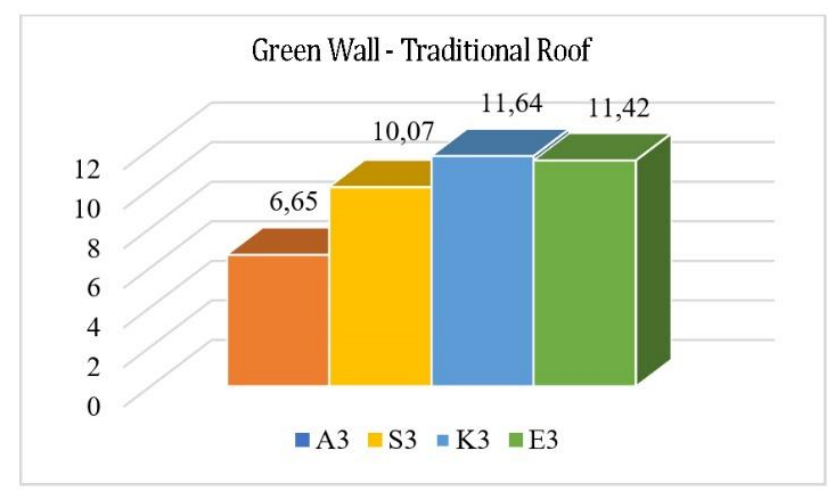

Figure 9. Benefit rates in green walls and traditional roofs $(\%)$

In Figure 10, the benefit rates obtained in annual total energy consumption by using green walls and green roofs for four cities are given. According to this chart, the highest rate of benefit achieved by using traditional walls and green roofs is realized with $14.38 \%$ in Erzurum city located in the 4th climate zone. This is followed by Konya located in the 3rd climate zone with $13.25 \%$, Samsun in the 2nd climate zone with $11.50 \%$ and Antalya in the 1st climate zone with $10.17 \%$.

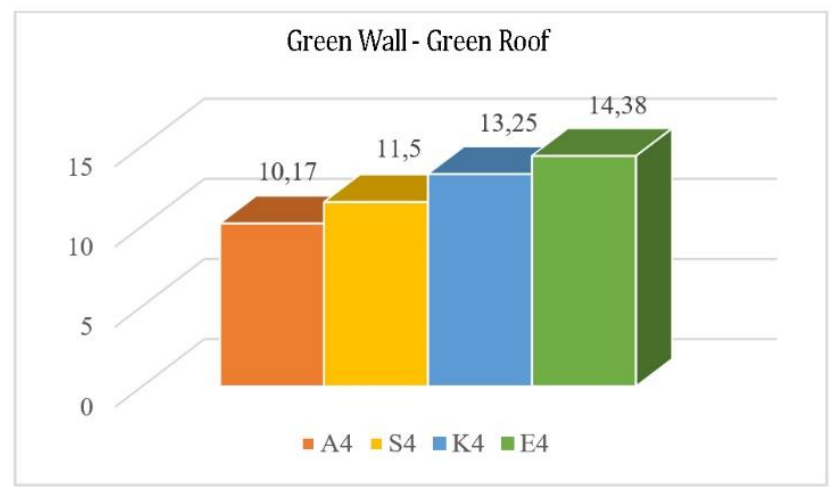

Figure 10. Benefit rates in green walls and green roofs (\%) 


\section{Discussion and conclusion}

In the study, simulations were made using different parameters and annual total energy consumption, annual heating consumption and annual cooling consumption have been compared for four different climatic regions of Turkey. In the simulations, it was determined in which climate zone the use of green roofs and green walls provided more positive effects than traditional roofs and traditional walls. In the calculations, it has been numerically proven that the use of green roofs and green walls provides a significant reduction in the annual total energy consumption for all regions. The findings resulting from the analysis are as follows:

- Annual total energy consumption is less in all options using green roofs and green walls compared to all options using traditional roofs and traditional walls. Therefore, greening the roof or facade of the building saves the total annual consumption energy.

- The annual heating energy consumption for all four different cities is the highest in data 1 using traditional roof and traditional wall, followed by data 2 using the green roof and traditional wall, followed by data 3 using the traditional roof and green wall. The annual heating energy consumption is the least in data 4 , which the green roof and green wall are used. Therefore, as can be understood from these data, green roof and green wall provide savings in the annual heating energy consumption for all four climatic zones.

- For Antalya city, the use of green roofs and green walls shows a decrease in annual cooling energy consumption from data 1 to 4 . In other words, for data 4 , which green roof and green wall are used, annual cooling energy consumption is the least. Therefore, for Antalya which located in one of the hottest climates of Turkey, using greening provides a lot of savings, especially for the summer months. Likewise, with the vegetation, shading is provided inside and outside the building and this creates comfortable spaces for people.

- For Samsun city, annual cooling energy consumption is the highest in the option which traditional roof and traditional wall are used. This is followed by the data 3 using traditional roof and green wall, followed by the data 2 using green roof and traditional wall. The least value is the data 4 which uses green roof and green wall. Therefore, using only green walls in
Samsun city provides less savings in annual cooling energy consumption compared to using only green roofs. However, using vegetation on both roof and wall provides savings in annual cooling energy consumption. Greening only on the roof, only the wall, or both provides a considerable savings compared to the use of traditional roofs and walls.

- For Konya city, annual cooling energy consumption is the highest data 2 which the green roof and traditional wall are used. This is followed by data 3 with a green wall and traditional roof. Then comes data 1 which includes the traditional roof and traditional wall. In this context, using only a green wall or only green roof causes damage to the annual cooling energy consumption for Konya city. However, for both options, savings are achieved in the annual total energy consumption. Data 4 which the green roof and green wall are used, is the least annual cooling energy consumption. In other words, the minimum cooling consumption occurs for a building with green roof and green wall in Konya.

- For Erzurum city, annual cooling energy consumption is the highest data 3 which green wall and traditional roof are used. This is followed by data 4, using green roof and green wall, and then data 1 , using traditional roof and traditional wall. The least valuable option is the data 2, with a green roof and traditional wall. However, using only a green wall or both a green roof and green wall harms the annual cooling energy consumption, but also saves on total energy consumption. Therefore, in a city like Erzurum where the summers are cold, it is a logical solution to use these systems since the annual cooling energy consumption will not be much, as it reduces the annual heating energy consumption and the total energy consumption.

- Comparison of the benefit rates in the four cities for the data 2 which green roof and traditional wall are used are Samsun with $2.68 \%$, Erzurum with $2.67 \%$, Antalya with $2.45 \%$ and Konya with $0.76 \%$. While these values are close to each other for Samsun, Erzurum and Antalya, this value is lower for Konya. Therefore, the use of green roofs and traditional walls provides considerable benefits to the annual total energy consumption for Samsun, Erzurum and Antalya, but less for Konya. 
- Comparison of the benefit rates in the four cities for the data 3 which traditional roof and green walls are used are Konya with $11.64 \%$, Erzurum with $11.42 \%$, Samsun with $10.07 \%$ and Antalya with $6.65 \%$. Thus, using traditional roofs and green walls provides more benefits for Konya, Erzurum and Samsun, but less benefit for the city of Antalya.

- Comparison of the benefit rates in the four cities for the data 4 which green roof and green wall are used are Erzurum with 14.38\%, Konya with $13.25 \%$, Samsun with $11.50 \%$ and Antalya with $10.17 \%$. Therefore, using green roofs and green walls are beneficial for Erzurum, Konya, Samsun and Antalya. This situation is directly related to the climatic conditions of these cities. While the highest benefit rate is seen in Erzurum, which has the coldest climate, Antalya, which has the warmest climate, provides the least benefit rate.

As a result, green walls and green roofs are new and sustainable solutions in architecture. Although it has some disadvantages; It has many positive features such as regulating air quality, reducing the urban heat island effect, reducing and increasing the temperature, saving in energy consumption, positively affecting human health, and providing noise and wind insulation. For this reason, green walls and green roofs are environmentally friendly systems, making cities more livable and comfortable. Especially in the long run, the benefits for people, the building and the city should not be overlooked.

\section{References}

Aksoy, Y. ve İçmek, S. (2010). Çatı bahçelerinin kent yaşamındaki yeri ve önemi: İstanbul kentinden örnekler. 5. Ulusal Çatı ve Cephe Sempozyumu, 15-16 Nisan, 15-16. İzmir.

Aktacir, M. A., Nacar, M. A. ve Yeşilata, B. (2011). Binalarda enerji verimliliği amaçlı yazılımlar üzerine kısa bir değerlendirme. $X$. Ulusal Tesisat Mühendisliği Kongresi, 13-16 Nisan, 853-862. İzmir.

Alexandri, E. and Jones, P. (2008). Temperature decreases in an urban canyon due to green walls and green roofs in diverse climates. Building and Environment, 43(4), 480-493. https://doi.org/10.1016/j.buildenv.2006.10.055

Altensis. (2015). Design Builder Yazılımı. http://www.altensis.com: (Access date: 19.06.2017).
Andric, I., Kamal, A. and Al-Ghamdi, S. G. (2020). Efficiency of green roofs and green walls as climate change mitigation measures in extremely hot and dry climate: Case study of Qatar. Energy Reports, 6, 2476-2489. https://doi.org/10.1016/j.egyr.2020.09.006.

Asadi, A., Arefi, H. and Fathipoor, H. (2020). Simulation of green roofs and their potential mitigating effects on the urban heat island using an artificial neural network: A case study in Austin, Texas. Advances in Space Research, 66(8), 1846-1862. https://doi.org/10.1016/j.asr.2020.06.039.

Azkorra, Z., Pérez, G., Coma, J., Cabeza, L. F., Burés, S., Álvaro, J. E., Erkoreka, A. and Urrestarazu, M. (2015). Evaluation of green walls as a passive acoustic insulation system for buildings. Applied Acoustics, $\quad 89, \quad 46-56$. https://doi.org/10.1016/j.apacoust.2014.09.010.

Baik, J. J., Kwak, K. H., Park, S. B. and Ryu, Y. H. (2012). Effects of building roof greening on air quality in street canyons. Atmospheric Environment, $61, \quad 48-55$. https://doi.org/10.1016/j.atmosenv.2012.06.076.

Besir, A. B. and Cuce, E. (2018). Green roofs and facades: A comprehensive review. Renewable and Sustainable Energy Reviews, 82, 915-939. https://doi.org/10.1016/j.rser.2017.09.106.

Coma, J., Pérez, G., de Gracia, A., Burés, S., Urrestarazu, M. and Cabeza, L. F. (2017). Vertical greenery systems for energy savings in buildings: A comparative study between green walls and green facades. Building and environment, $111, \quad 228-237$. https://doi.org/10.1016/j.buildenv.2016.11.014.

Dede, O. H., Mercan, N., Ozer, H., Dede, G., Pekarchuk, O. and Mercan, B. (2021). Thermal insulation characteristics of green wall systems using different growing media. Energy and Buildings, 240 , 110872. https://doi.org/10.1016/j.enbuild.2021.110872.

Design Builder Software Ltd. (2017) https://www.designbuilder.co.uk/ (Access date: 22.11.2017).

Francis, J., Hall, G., Murphy, S., and Rayner, J. (2014). Growing Green Guide: A guide to green roofs, walls and facades in Melbourne and Victoria. Australia. State of Victoria through the Department of Environment and Primary Industries, National Library of Australia Cataloguing, ISBN 978-1-74326-715-8.

Galbrun, L. and Scerri, L. (2017). Sound insulation of lightweight extensive green roofs. Building and Environment, 116, 130-139. https://doi.org/10.1016/j.buildenv.2017.02.008. 
Hasan, M. M., Karim, A., Brown, R. J., Perkins, M. and Joyce, D. (2012). Estimation of Energy Saving of Commercial Building by Living Wall and Green Facade in Subtropical Climate of Australia. The 7th International Green Energy Conference and The 1st DNL Conference on Clean Energy, IGEC-DCCE, May 28-30, (pp 1-13). Dalian, China.

Herath, H. M. P. I. K., Halwatura, R. U. and Jayasinghe, G. Y. (2018). Modeling a tropical urban context with green walls and green roofs as an urban heat island adaptation strategy. Procedia Engineering,212, 691-698. https://doi.org/10.1016/j.proeng.2018.01.089.

Jones, R. A. (2002). Tecticolous Invertebrates: A preliminary investigation of the invertebrate fauna on green roofs in urban London. English Nature, London, 1-36.

Jungels, J., Rakow, D. A., Allred, S. B. and Skelly, S. M. (2013). Attitudes and aesthetic reactions toward green roofs in the Northeastern United States. Landscape and Urban Planning, 117, 1321.

https://doi.org/10.1016/j.landurbplan.2013.04.0 13.

Jusselme, M. D., Pruvost, C., Motard, E., Giusti-Miller, S., Frechault, S., Alphonse, V., Balland-BolouBi, C., Dajoz, I. and Mora, P. (2019). Increasing the ability of a green roof to provide ecosystem services by adding organic matter and earthworms. Applied soil ecology, 143, 61-69. https://doi.org/10.1016/j.apsoil.2019.05.028.

Kobya, H. B. (2017). Düşey yeşil cepheler ve yeşil çatıların ekolojik kriterler bakımından incelenmesi ve enerji verimliliğinin değerlendirilmesi. Selçuk Üniversitesi, Fen Bilimleri Enstitüsü, Yüksek Lisans Tezi, Konya.

Köppen İklim Sinıflandırmas1. http://koeppengeiger.vu-wien.ac.at/ (Access date: 15.06.2017).

Liu, H., Kong, F., Yin, H., Middel, A., Zheng, X., Huang, J., Hairong, X., Wang, D. and Wen, Z. (2021). Impacts of green roofs on water, temperature, and air quality: A bibliometric review. Building and Environment, 107794. https://doi.org/10.1016/j.buildenv.2021.107794.

Loh, S. (2008). Living Walls-A Way to Green the Built Environment. Environment Design Guide, pp 17. http://www.jstor.org/stable/26149051.

Luckett, K. (2009). Green roof construction and maintenance. McGraw-Hill Education, pp 208.

MacDonagh, L. P. (2005). Benefits of Green Roofs. Implications, 04(08), 1-3.
Manso, M., Teotónio, I., Silva, C. M. and Cruz, C. O. (2021). Green roof and green wall benefits and costs: A review of the quantitative evidence. Renewable and Sustainable Energy Reviews, 135 , 110111 . https://doi.org/10.1016/j.rser.2020.110111.

Mazzali, U., Peron, F. and Scarpa, M. (2012). Thermophysical performances of living walls via field measurements and numerical analysis. WIT Transactions on Ecology and the Environment, 165, 251-259.

Mentens, J., Raes, D. and Hermy, M. (2006). Green roofs as a tool for solving the rainwater runoff problem in the urbanized 21st century? Landscape and Urban Planning, 77(3), 217-226. https://doi.org/10.1016/j.landurbplan.2005.02.0 10.

Mir, M. (2011). Green Facades and Building Structures. $\mathrm{Tu}$ Delft University, Faculty of Civil Engineering-Section Materials and Environments, Master Thesis, Delft.

Nieuwenhuijsen, M. and Khreis H. (2019). Green space and health. In Integrating human health into urban and transport planning (pp. 409-423). Springer, Cham.

Papadakis, G., Tsamis, P. and Kyritsis, S., (2001). An experimental investigation of the effect of shading with plants for solar control of buildings. Energy and Buildings, 33(8), 831-836. https://doi.org/10.1016/S0378-7788(01)000664.

Peck, S. W., Callaghan, C., Kuhn, M. E. and Bass, B. (1999). Greenbacks From Green Roofs: Forging a New Industry in Canada. Canada Mortgage \& Housing Corporation, Canada, pp 78. http://citeseerx.ist.psu.edu/viewdoc/download?d $\mathrm{oi}=10.1 \cdot 1.196 .7020 \& \mathrm{rep}=\mathrm{rep} 1 \&$ type $=$ pdf.

Perez, G., Rincon, L., Vila, A., Gonzalez, J. M. and Cabeza, L. F. (2011). Green Vertical Systems for Buildings as Passive Systems for Energy Savings. Applied Energy, 88(12), 4854-4859. https://doi.org/10.1016/j.apenergy.2011.06.032.

Pérez Luque, G., Coma Arpón, J., Sol i Felip, S. and Cabeza, L. F. (2017). Green facade for energy savings in buildings: The influence of leaf area index and facade orientation on the shadow effect. Applied Energy, 187, 424-437. https://doi.org/10.1016/j.apenergy.2016.11.055.

Saadatian, O., Sopian, K., Salleh, E., Lim, C. H., Riffat, S., Saadatian, E., Toudeshki A. and Sulaiman, M. Y. (2013). A review of energy aspects of green roofs. Renewable and Sustainable Energy Reviews, 23, 155-168. https://doi.org/10.1016/j.rser.2013.02.022. 
Sanchez, L. and Reames, T. G. (2019). Cooling Detroit: A socio-spatial analysis of equity in green roofs as an urban heat island mitigation strategy. Urban Forestry \& Urban Greening, 44, 126331. https://doi.org/10.1016/j.ufug.2019.04.014.

Scholz-Barth, K. (2001). Green Roofs: Stormwater Management From the Top Down. Environmental Design and Construction, 4(1), 63-69.

Susorova, I. (2015). Green facades and living walls: vertical vegetation as a construction material to reduce building cooling loads. In Eco-Efficient Materials for Mitigating Building Cooling Needs (pp. 127-153). Woodhead Publishing.

Sutton, R. K. (2014). Aesthetics for green roofs and green walls. Journal of Living Architecture. Issue 2 , March. https://digitalcommons.unl.edu/arch_land_facult yschol/19/.

Tilley, D., Price, J., Matt, S. and Marrow, B. (2012). Vegetated Walls: Thermal and Growth Properties of Structured Green Facades. Final Report to Green Roofs for Healthy Cities-Green Walls Group. Environmental Science and
Technology Department College of Agriculture and Natural Resources, Agricultural Experiment Station, University of Maryland, College Park, $p$ 163.

Ulrich, R. (1984). View through a window may influence recovery. Science, 224(4647), 224225. Doi: 10.1126/science.6143402.

Vox, G., Blanco, I. and Schettini, E. (2018). Green façades to control wall surface temperature in buildings. Building and Environment, 129, 154166.

https://doi.org/10.1016/j.buildenv.2017.12.002.

Wong, N. H., Tan, A. Y. K., Tan, P. Y., Chiang, K. and Wong, N. C. (2010). Acoustics evaluation of vertical greenery systems for building walls. Building and Environment, 45(2), 411-420. https://doi.org/10.1016/j.buildenv.2009.06.017.

Xu, L., Yang, S., Zhang, Y., Jin, Z., Huang, X., Bei, K., Zhao, M., Kong, H. and Zheng, X. (2020). A hydroponic green roof system for rainwater collection and greywater treatment. Journal of Cleaner Production, 261, 121132. https://doi.org/10.1016/j.jclepro.2020.121132. 